\title{
Anchimolgus gratus n. sp. (Copepoda: Poecilostomatoida: Anchimolgidae), associated with the scleractinian coral Lithactinia novaehiberniae in New Caledonia
}

\author{
Arthur G. Humes \\ Boston University Marine Program, Marine Biological Laboratory, Woods Hole, Massachusetts 02543, \\ U.S.A.
}

Keywords: Copepoda, Poecilostomatoida, Anchimolgus, associate, scleractinian coral, New Caledonia

\begin{abstract}
Anchimolgus gratus n. sp., associated with the fungiid coral Lithactinia novaehiberniae Lesson, 1831 in New Caledonia, is distinguished from its congeners (except $A$. pandus Humes, 1978) by the formula III,I,5 on the third segment of the exopod of leg 4. The new species differs from $A$. pandus which is much smaller and in which the female genital double-somite is as long as wide.
\end{abstract}

\section{Introduction}

The copepod genus Anchimolgus Humes \& Stock, 1972 , is widespread in the tropical Indo-Pacific from Madagascar to the Moluccas and New Caledonia. Twenty species are known to be associated with various Scleractinia (Acrhelia, Echinopora, Favia, Fungia, Galaxea, Goniopora, Herpolitha, Parahalomitra, Polyphyllia, and Porites), and one species with a corallimorpharian (Pseudocorynactis).

In this paper, a new species of Anchimolgus is described from a rarely collected, shallow-water reef coral, Lithactinia novaehiberniae Lesson, 1831, whose distribution, according to Lamberts (1984), is "limited to a relatively small area in the southwest Pacific" (Solomon Islands, New Caledonia, Fiji, Tonga, and American Samoa). Lithactinia was synonymized with Polyphyllia by Veron \& Pichon (1979), but recognized as a valid genus by Lamberts (1984).

\section{Materials and methods}

The coral was isolated in seawater in a plastic bag immediately after collection. On board ship, sufficient $95 \%$ ethanol was added to make approximately a $5 \%$ solution. In this the coral was thoroughly soaked and rinsed. The water was then passed through a fine net $(120$ holes per $2.5 \mathrm{~cm})$ and the copepods recovered from the sediment retained in the net.

All figures were drawn with the aid of a camera lucida.

\section{Taxonomic part}

Poecilostomatoida Thorell, 1859

Anchimolgidae Humes \& Boxshall, 1996

Anchimolgus Humes \& Stock, 1972

Anchimolgus gratus n. sp.

(Figs. 1a-e, 2a-h, 3a-h, 4a-i)

Type material.- Eight $९$, five $\sigma^{\circ} \sigma$ from one Lithactinia novaehiberniae Lesson, in a depth of $20 \mathrm{~cm}$, reef at eastern end of Ile Maître, near Noumea, New Caledonia, 22 $20^{\prime} 35^{\prime \prime} \mathrm{S}$, $166^{\circ} 25^{\prime} 10^{\prime \prime} \mathrm{E}, 31$ July 1971 . Holotype \& (ZMA Co. 202018a), allotype $\sigma^{\circ}$ (ZMA Co. 202018b), and 7 paratypes (5 ९ , 2 $\sigma^{\circ} \sigma^{\circ}$ ) (ZMA Co. 202018c) deposited in the Zoölogisch Museum, Amsterdam. Remaining paratypes (dissected) in the collection of the author.

Female.- Body (Fig. 1a) with moderately wide prosome. Average length (not including setae on caudal rami) $1.85 \mathrm{~mm}(1.74-1.98 \mathrm{~mm})$ and greatest width $0.75 \mathrm{~mm}(0.68-0.79 \mathrm{~mm})$, based on 8 specimens in lactic acid. Epimera of metasomal somites rounded posteriorly. Ratio of length to 
width of prosome $1.58: 1 \mathrm{~mm}$. Ratio of length of prosome to that of urosome $1.55: 1$.

Somite bearing leg 5 (Fig. 1b) $125 \times 297 \mu \mathrm{m}$. Genital double-somite in dorsal view $253 \times 324$ $\mu \mathrm{m}$, broader than long, ratio $0.78: 1$; in lateral view (Fig. 1c) slender $242 \times 109 \mu \mathrm{m}$. Sides of double-somite slightly irregular in anterior five-sixths, abruptly narrowed and parallel in posterior sixth. Genital areas located dorsolaterally in posterior half of double-somite, each area with 2 very unequal setae $77 \mu \mathrm{m}$ and $18 \mu \mathrm{m}$ long (Fig. $1 \mathrm{~b}, \mathrm{~d}$ ). Three postgenital somites from anterior to posterior $75 \times 133,70 \times 130$, and $117 \times 145 \mu \mathrm{m}$.

Caudal ramus (Fig. 1e) unornamented, $117 \times 65$ $\mu \mathrm{m}$, ratio $1.8: 1$. Outer lateral seta $275 \mu \mathrm{m}$, dorsal seta $94 \mu \mathrm{m}$, outermost terminal seta $220 \mu \mathrm{m}$, innermost terminal seta $385 \mu \mathrm{m}$, and 2 median terminal setae $715 \mu \mathrm{m}$ (outer) and $770 \mu \mathrm{m}$ (inner), all with lateral setules.

Body surface without visible sensilla.

Egg sac not seen.

Rostrum (Fig. 2a) broadly rounded posteroventrally. Antennule (Fig. 2b) $682 \mu \mathrm{m}$ long. Lengths of its 7 segments (measured along their posterior nonsetiferous margins): $65(104 \mu \mathrm{m}$ along anterior margin), 234, 44, 136, 83, 62, and $35 \mu \mathrm{m}$, respectively. Armature: 4, 13, 6, 3, $4+1$ aesthetasc, $2+1$ aesthetasc, and $7+1$ aesthetasc. All setae smooth. Antenna (Fig. 2c) 4-segmented, armature $1,1,3$, and 1 claw. Third segment $99 \mu \mathrm{m}$, fourth segment $34 \mu \mathrm{m}$, and claw (Fig. 2d) $63 \mu \mathrm{m}$.

Labrum (Fig. 2e) with 2 broad posteroventral lobes. Mandible (Fig. 2f) with proximal part having 2 small digitiform processes on convex side and 2 lobes bearing marginal spinules on concave side. Lash with few long setules proximally on outer side and short bilateral barbs distally. Paragnath a small lobe. Maxillule (Fig. $2 \mathrm{~g}$ ) a slender lobe with 4 setae. Maxilla (Fig. 2h) 2-segmented, first segment unarmed, second segment with outer and inner seta, and lash with setules along convex side, proximalmost setule stouter than others. Maxillipede (Fig. 3a) 3-segmented, with 2 setae on second segment; third segment also with 2 setae and terminating in small recurved tip.

Ventral area between maxillipedes and first pair of legs (Fig. 3b) not protuberant.

Legs 1-4 (Fig. 3c-f) with 3-segmented rami, ex- cept 2-segmented endopod in leg 4. Formula for armature (Roman numerals indicating spines, Arabic numerals representing setae) as follows:

\begin{tabular}{|c|c|c|c|c|c|}
\hline$P_{1}$ & $\operatorname{coxa} 0-1$ & basis $1-0$ & $\begin{array}{l}\exp \mathrm{I}-0 \\
\operatorname{enp} 0-1 ;\end{array}$ & $\begin{array}{l}\text { I-1; } \\
0-1 ;\end{array}$ & $\begin{array}{l}\text { III,I,4 } \\
\text { I,5 }\end{array}$ \\
\hline 2 & $\operatorname{coxa} 0-1$ & basis $1-0$ & $\begin{array}{l}\exp \text { I-0; } \\
\text { enp } 0-1\end{array}$ & $\begin{array}{l}\text { I-1; } \\
0-2 ;\end{array}$ & $\begin{array}{l}\text { III,I,5 } \\
\text { I,II,3 }\end{array}$ \\
\hline$P_{3}$ & $\operatorname{coxa} 0-1$ & basis $1-0$ & $\begin{array}{l}\exp \text { I-0; } \\
\text { enp 0-1; }\end{array}$ & $\begin{array}{l}\text { I-1; } \\
0-2 ;\end{array}$ & $\begin{array}{l}\text { III,I,5 } \\
\text { I,II,2 }\end{array}$ \\
\hline & $\operatorname{coxa} 0-1$ & basis 1-0 & $\begin{array}{l}\exp \mathrm{I}-0 \text {; } \\
\operatorname{enp} 0-1 ;\end{array}$ & $\begin{array}{l}\text { I-1; } \\
\text { II }\end{array}$ & III,I,5 \\
\hline
\end{tabular}

Coxa of leg 1 with slight protuberance on outer posterior surface (Fig. 3c). Leg 4 with inner seta on coxa $13 \mu \mathrm{m}$; exopod $217 \mu \mathrm{m}$ long, endopod (Fig. $3 \mathrm{~g}$ ) with first segment $36 \times 34 \mu \mathrm{m}$, its inner plumose seta $65 \mu \mathrm{m}$; second segment $68 \times 26 \mu \mathrm{m}$, its 2 terminal barbed spines 56 and $100 \mu \mathrm{m}$ (outer spine slightly bulbous proximally). Both endopodal segments with outer marginal hairlike setules.

Leg 5 (Fig. 3h) with free segment $148 \times 49 \mu \mathrm{m}$, ratio $3: 1$. Two terminal setae 135 and $200 \mu \mathrm{m}$. Seta on body near insertion of free segment $65 \mu \mathrm{m}$. Free segment ornamented on outer side with small spinules.

Leg 6 represented by 2 unequal setae on genital area (Fig. 1d).

Color of living specimens in transmitted light opaque gray, eye red.

Male.- Body (Fig. 4a) with prosome more slender than in female. Average length $1.42 \mathrm{~mm}$ (1.35$1.52 \mathrm{~mm})$ and greatest width $0.53 \mathrm{~mm}(0.50-0.56$ $\mathrm{mm})$, based on 4 specimens. Ratio of length to width of prosome $1.76: 1$. Ratio of length of prosome to that of urosome $1.26: 1$.

Somite bearing leg 5 (Fig. 4b) $65 \times 192 \mu \mathrm{m}$. Genital somite in dorsal view quadrate, $330 \times 335$ $\mu \mathrm{m}$ with rounded sides; in lateral view (Fig. 4c) slender. Length of genital somite $363 \mu \mathrm{m}$ including leg 6. Four postgenital somites from anterior to posterior $44 \times 99,47 \times 99,34 \times 99$, and $48 \times 117$ $\mu \mathrm{m}$.

Caudal ramus (Fig. $4 \mathrm{~b}$ ) resembling that of female, but smaller, $94 \times 52 \mu \mathrm{m}$, ratio $1.8: 1$.

Rostrum like that of female. Antennule similar to that of female but with 3 additional aesthetascs (at points indicated by dots in Fig. 2b). Antenna (Fig. 4d) resembling that of female, but having 


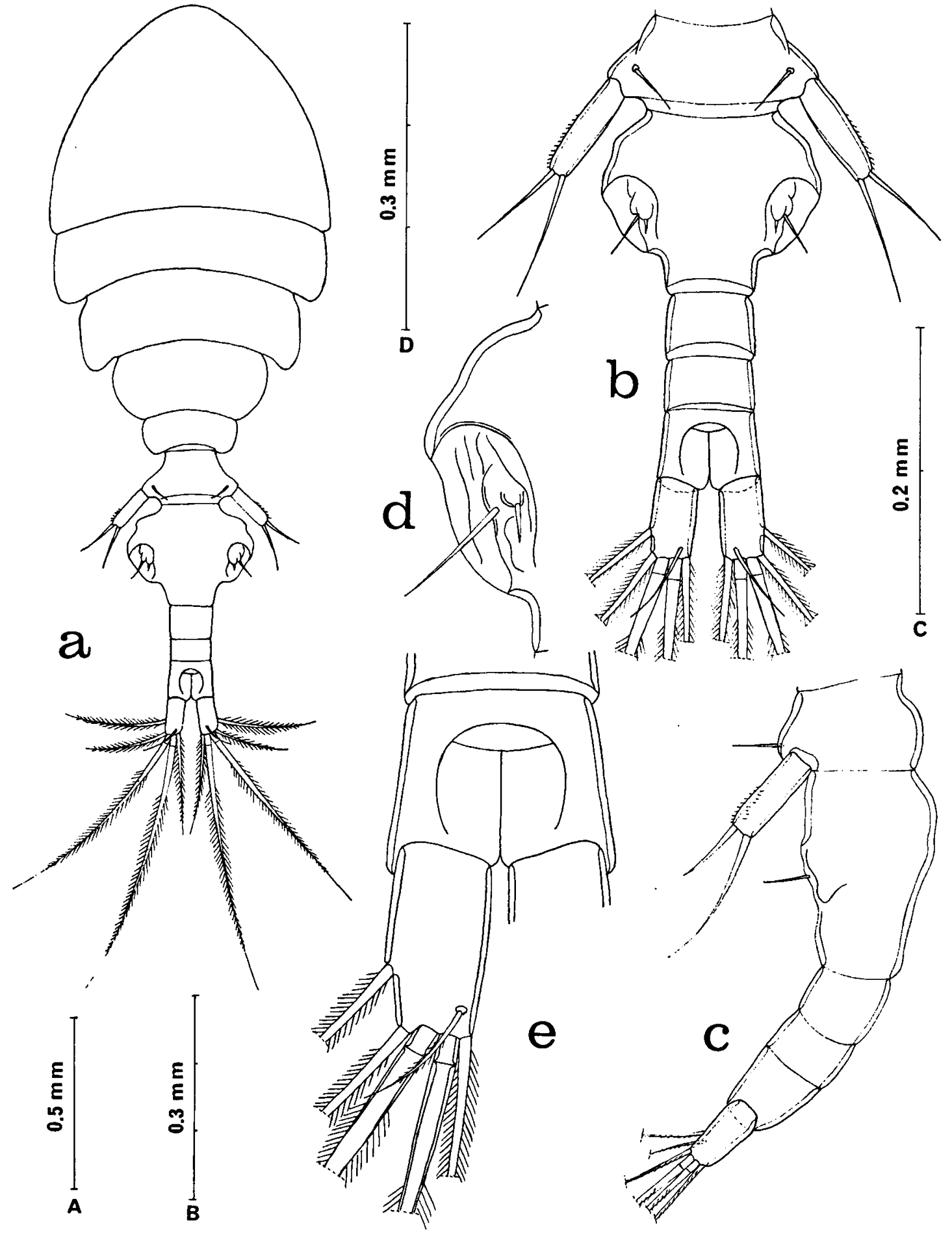

Fig. 1. Anchimolgus gratus n. gen., n. sp., $\$$ : a, habitus, dorsal (scale A); b, urosome, dorsal (B); c, urosome, lateral (B); d, genital area, dorsal (C); e, anal somite and caudal ramus, dorsal (D). 

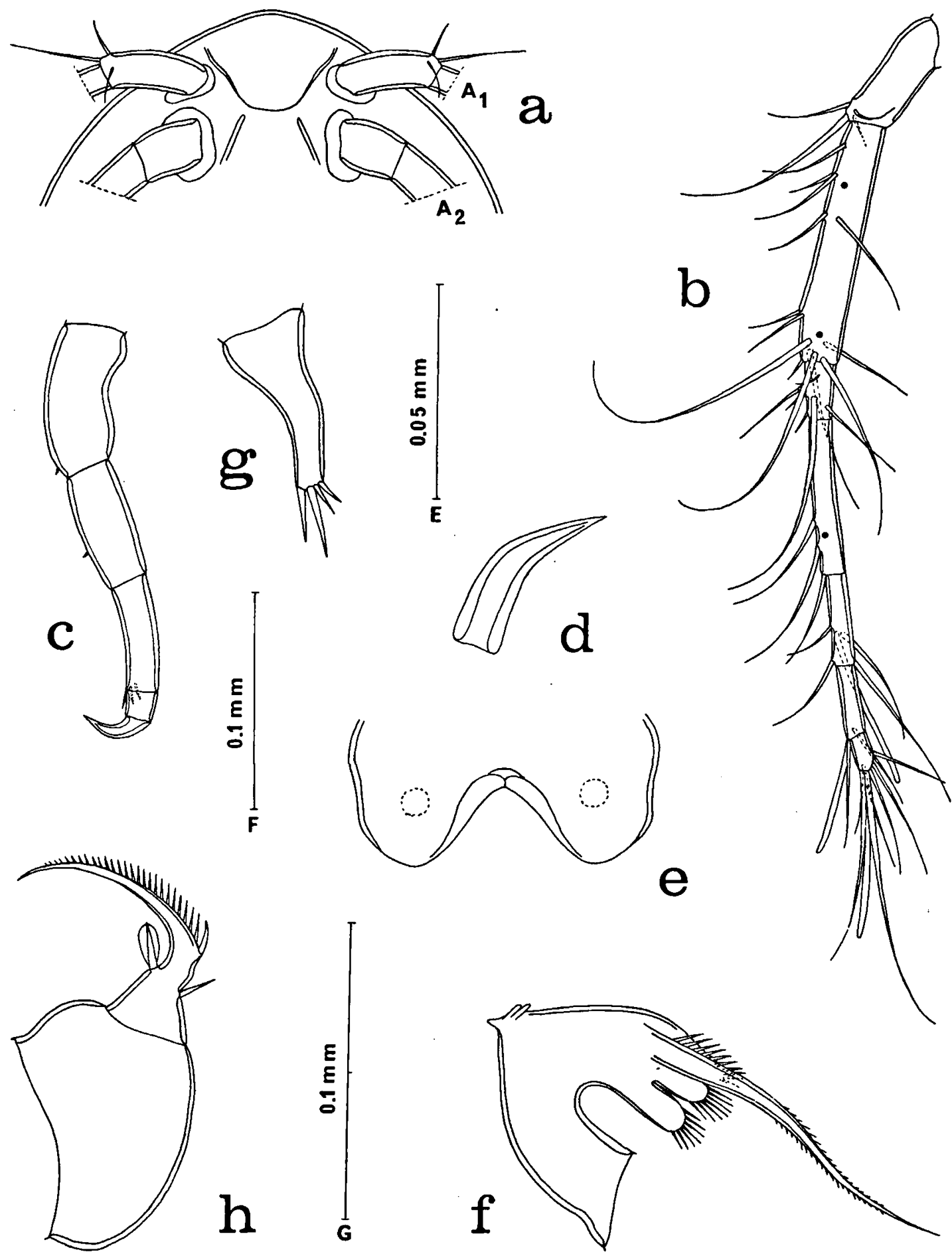

Fig. 2. Anchimolgus gratus n. gen., n. sp., ९: a, rostrum, ventral (scale B); b, antennule, with three dots indicating positions of aesthetascs in male, dorsal (D); c, antenna, antero-inner (D); d, claw on antenna, antero-inner (E); e, labrum, with broken lines showing position of paragnaths, ventral $(\mathrm{F})$; $f$, mandible, posterior $(\mathrm{G})$; $\mathrm{g}$, maxillule, posterior $(\mathrm{G})$; $h$, maxilla, anterior $(\mathrm{F})$. 

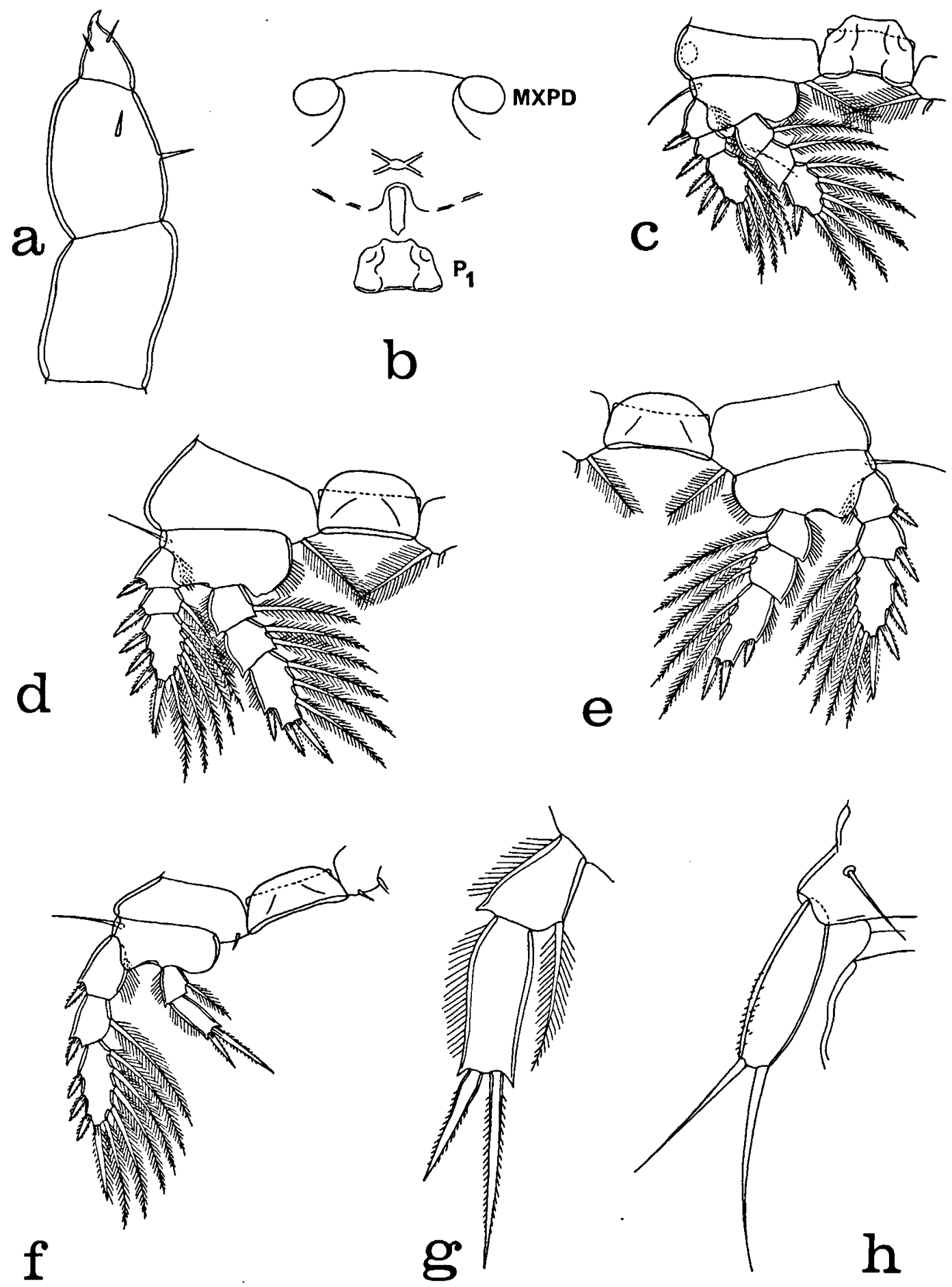

Fig. 3. Anchimolgus gratus n. gen., n. sp., $९$ : a, maxillipede, postero-inner (scale F); b, area between maxillipedes and first pair of legs, ventral (B); c, leg 1 and intercoxal plate, anterior (B); d, leg 2 and intercoxal plate, anterior (B); e, leg 3 and intercoxal plate, anterior (B); f, leg 4 and intercoxal plate, anterior (B); g, endopod of leg 4, anterior (F); h, leg 5, dorsal (D). 

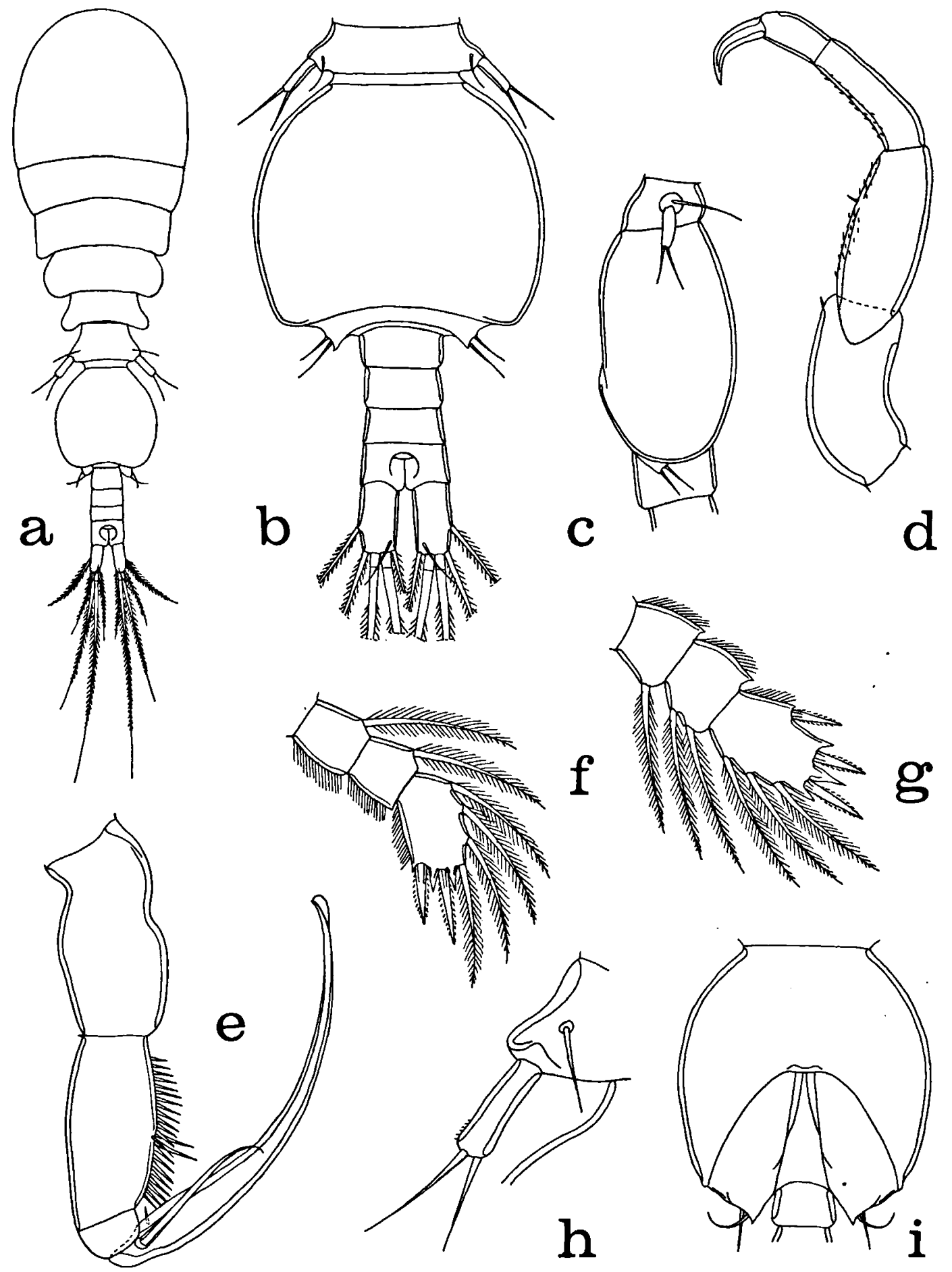

Fig. 4. Anchimolgus gratus n. gen., n. sp., o : a, habitus, dorsal (scale A); b, urosome, dorsal (B); c, somite bearing leg 5, genital somite, and first postgenital somite, lateral (B); d, antenna, antero-inner (C); e, maxillipede, inner (C); f, endopod of leg 1, anterior (C); $\mathrm{g}$, endopod of leg 2, anterior (C); h, leg 5, dorsal (F); i, genital somite and first postgenital somite, ventral (B). 
small spines along inner surface of second and third segments. Third segment $83 \mu \mathrm{m}$ long, fourth segment $46 \mu \mathrm{m}$. Claw $45 \mu \mathrm{m}$.

Labrum, mandible, paragnath, maxillule, and maxilla like those of female. Maxillipede (Fig. 4e) 4-segmented, assuming claw to represent fourth segment. Second segment with 2 setae and row of setules. Claw $255 \mu \mathrm{m}(260 \mu \mathrm{m}$ including terminal lamella), armed proximally with 2 very unequal setae, longer seta with recurved tip.

Ventral area between maxillipedes and first pair of legs as in female.

Leg 1 with armature of endopod $0-1 ; 0-1 ; \mathrm{I}, \mathrm{I}, 4$ (Fig. 4f). Leg 2 with third endopodal segment having enlarged median terminal spiniform process (Fig. 4g). Otherwise legs 1-4 like those of female.

Leg 5 (Fig. 4h) with free segment $52 \mu \mathrm{m}$ long, more slender than in female. Least width $13 \mu \mathrm{m}$, greatest width $15 \mu \mathrm{m}$ (ratio of length to width 3.36 : 1).

Leg 6 (Fig. 4i) represented by posteroventral flap on genital somite bearing 2 setae.

Color as in female.

Etymology.- The specific name gratus (Latin), meaning pleasing, alludes to the graceful body form.

Remarks.- Twenty-one species, including the new species described above, are placed in the genus Anchimolgus (see key provided by Humes, 1996). Twelve species may be readily distinguished from Anchimolgus gratus by having the female genital double-somite distinctly longer than wide: $A$. abbreviatus Humes, 1991, A. compressus Humes, 1996, A. convexus Humes, 1978, A. exsertus Humes, 1991, A. latens Humes, 1978, $A$. moluccanus Humes, 1996, $A$. nasutus Humes, 1996, $A$. notatus Humes, 1978, $A$. orectus Humes, 1978, $A$. prolixipes Humes \& Ho, 1968, A. tenaus Humes, 1991, and $A$. tener Humes, 1973. Selected characters of the remaining eight species distinguish them from the new species. In $A$. digitatus Humes \& Ho, 1968, A. gigas Humes, 1995, and A. mimeticus Humes, 1995, the ratio of length to width of the caudal ramus is more than $3: 1$. In $A$. conformatus Humes, 1995, the free segment of leg 5 has a length to width ratio of $5.2: 1$. In $A$. punctilis
Humes, 1978, and $A$. cuneatus Stock, 1990, the free segment of leg 5 has a proximal inner expansion. In $A$. pandus Humes, 1978, the genital double-somite is as long as wide. In $A$. breviarius Humes, 1995, the female is unknown. However, the body length of the male is $1.09 \mathrm{~mm}(1.07-1.13$ $\mathrm{mm}$ ), distinctly less than in $A$. gratus, and the formula for the third segment of the exopod of leg 4 is II,I,5, rather than III,I,5 as in the new species.

In untransformed lichomolgoid copepods the number of spines on the third segment of the exopod of leg 4 is either II,I,5 or III,I,5. This feature was used as a criterion by Humes \& Stock (1983) when they separated Doridicola Leydig, 1853, with II,I,5, from Critomolgus Humes \& Stock, 1972, with III,I,5. Several genera as presently conceived contain species with both II,I,5 and III,I,5, for example, Panjakus Humes \& Stock, 1973, and Odontomolgus Humes \& Stock, 1973. In Anchimolgus, 19 species are armed with II,I,5 on the third segment of the exopod of leg 4, but $A$. pandus Humes, 1978, and the new species $A$. gratus have III,I,5. The significance of this difference in spination is not known.

The genus Anchimolgus, restricted to the IndoPacific (Madagascar, Great Barrier Reef, Flores Sea, Moluccas, New Caledonia), contains 20 species associated with scleractinian corals (Acrhelia, Echinopora, Fungia, Galaxea, Goniopora, Herpolitha, Lithactinia, Parahalomitra, Polyphyllia, Porites) (Humes, 1973, 1978, 1991, 1995, 1996; Humes \& Ho, 1968) One species, $A$. cuneatus, lives with a corallimorpharian (Pseudocorynactis) in the Flores Sea, Indonesia (Stock, 1990).

\section{Acknowledgements}

I thank the staff at the Centre ORSTOM de Nouméa for their generous assistance. The late Dr. John W. Wells, Cornell University, identified the coral. This work was supported by grants (GB-8381X and BSR 8-21979) from the National Science Foundation of the United States.

The copepods were collected by the author during the Alpha Helix East Asian Bioluminescence Expedition (1975), which was supported by the National Science Foundation under grants OFS 7401830 and OFS 740288 to the Scripps Institution of Oceanography and grant BMS 7423242 to the University of California, Santa Barbara. 


\section{References}

Humes, A.G., 1973. Cyclopoid copepods (Lichomolgidae) from fungiid corals in New Caledonia. Zool. Anz., 190: 312-333.

Humes, A.G., 1978. Lichomolgid copepods (Cyclopoida) associated with fungiid corals (Scleractinia) in the Moluccas. Smithson. Contr. Zool., 253: 1-48.

Humes, A.G., 1991. Copepoda associated with scleractinian corals on the Great Barrier Reef, northeastern Australia, with a key to the genera of the Lichomolgidae. J. nat. Hist., 25: 1171-1231.

Humes, A.G., 1995. New species of Anchimolgus (Copepoda: Poecilostomatoida: Lichomolgidae) associated with the scleractian coral Goniopora in the southwest Pacific. J. nat. Hist., 29: 65-84.

Humes, A.G., 1996. Copepoda associated with the scleractinian coral Galaxea in the Indo-Pacific. Publs. Seto mar. biol. Lab., 37: 1-49.

Humes, A.G. \& G.A. Boxshall, 1996. A revision of the lichomolgoid complex (Copepoda: Poecilostomatoida), with the recognition of six new families. J. nat. Hist., 30: 175227.

Humes, A.G. \& J.-S. Ho, 1968. Lichomolgid copepods (Cyclopoida) associated with corals in Madagascar. Bull. Mus. comp. Zool., Harvard Univ., 136: 353-413.

Humes, A.G. \& J.H. Stock, 1972. Preliminary notes on a revision of the Lichomolgidae, cyclopoid copepods mainly associated with marine invertebrates. Bull. zool. Mus., Univ. Amsterdam, 2: 121-133.
Humes, A.G. \& J.H. Stock, 1973. A revision of the family Lichomolgidae Kossmann, 1877, cyclopoid copepods mainly associated with marine invertebrates. Smithson. Contr. Zool., 127: 1-368.

Humes, A.G. \& J.H. Stock, 1983. Redefinition of the genus Doridicola Leydig, 1853, synonymy of Metaxymolgus Humes \& Stock, 1972, and establishment of a new genus, Critomolgus (Copepoda, Poecilostomatoida, Lichomolgidae). Bull. zool. Mus. Univ. Amsterdam, 9: 93-96.

Lamberts, A.E., 1984. The reef corals Lithactinia and Polyphyllia (Anthozoa, Scleractinia, Fungiidae): a study of morphological, geographical, and statistical differences. Pac. Sci., 38: 12-27.

Leydig, F., 1852. Zoölogische Notizen 1. Neuer Schmarotzerkrebs auf einem Weichthier. Z. wiss. Zool., 4: 377382.

Stock, J.H., 1990. A new species of Anchimolgus (Copepoda: Poecilostomatoida: Lichomolgidae) associated with an Indian corallimorpharian. Zoöl. Meded., 63: 335-341.

Thorell, T., 1859. Till kännedomen om vissa parasitiskt lefvande Entomostraceer. Ofversigt af Kongl. VetenskapsAkad. Förh., 16: 335-362.

Veron, J.E.N. \& M. Pichon, 1979. Scleractinia of eastern Australia. Part III. Families Agariciidae, Siderasteridae, Fungiidae, Oculinidae, Merulinidae, Mussidae, Pectiniidae, Caryophylliidae, Dendrophylliidae. Austral. Inst. mar. Sci. Monogr. Ser., 4: i-ix, 1-441, [442-444].

Received: 18 April 1996 